also helped the tasks of the ophthalmologist. But the lack of any specific treatment for tuberculosis makes it difficult to control tuberculous allergy of the eye. Until we find an antisyphilitic agent which will reach and act on the brain and the eye, treatment of ocular syphilis will be unsatisfactory.

Among genetic affections of the eye, malformations and hereditary anomalies cause the blindness of some 50 per cent of blind children. Geneticists should find interesting material in the study of glioma retince, a disease which behaves as an irregular dominant in some families. We need to know why it does not behave as a dominant in those transmitters of it who do not suffer from it.

Among nutritional and metabolic disorders, xerophthalmia is a major problem in China and India. Work is needed on the correlation of nutrition with ocular health and we need better methods of studying the physiology of the eye, so that problems which, like diabetic retinitis, are related to faulty metabolism of the body as a whole, may be tackled on a proper basis. Such methods would also help the study of cataract and glaucoma, which are, according to English and North American statistics, responsible for 25-40 per cent of blindness.

Finally, in children and young adults, injuries are important. War is the greatest single cause of blindness, and it poses its own special problems-the extraction, for example, of non-magnetic fragments from the interior of the eye, such fragments being, in the present War, largely non-magnetic, while those encountered during the War of 1914-18 were not.

In a section on ocular hygiene Prof. Sorsby echoes the opinions of the leaders of modern medical thought when he reminds us that nowadays we tend to take 'optical aids' as a matter of course, and to forget the environmental conditions of those who have to use them. It is good to learn that England may have a national eye service for all, an important part of which will be the research facilities which are essential to its progress. The British Medical Bulletin points out that the Oxford University Ophthalmic Research Endowment Committee is appealing for funds for the endowment of the newly established Department of Ophthalmology at Oxford after the War. Reference was made to this project in NaTuRE of September 18, 1942, p. 323.

In another special article in this issue of the British Medical Bulletin, R. R. James gives an outline of the history of English ophthalmology since its beginnings in the days of the Roman occupation. After the Romans left, the Anglo-Saxons and Normans did little to improve ophthalmic practice, but in the thirteenth century Roger Bacon and John of Peckham initiated the use by old people of lenses for reading, and the science of optics began. Early in the seventeenth century the itinerant oculist Richard Banister of Stamford directed attention to hardness of the eyeball as a cardinal sign of glaucoma, a discovery which was forgotten for 150 years. Banister seems to have been an honest and remarkable member of an itinerant fraternity whose practices should make entertaining reading. Mr. James describes the eighteenth century as the age of ophthalmic quackery, but during it modern ophthalmology was founded by Cheselden, Sharp, Warner and others. In 1805 the Moorfields Eye Hospital, now the Royal London Ophthalmic Hospital, was founded. Exeter established an eye hospital in 1808 and Manchester in 1814. The subsequent landmarks in ophthalmic history given by Mr. James indicate that, when Sir William Bowman, who gave his name to Bowman's membrane, abandoned general surgery to become the first ophthalmic specialist, he began that specialist service which to-day must face so many urgent tasks.

G. LAPAGE.

\section{THIOUREA AS PROTECTIVE AGENT FOR VITAMIN C}

FOOD products rich in ascorbic acid, such as those made from citrus and other fruits, should be processed under conditions in which the vitamin is not destroyed. Ascorbic acid loses its antiscorbutic action when the cyclic structure of the molecule is changed by the opening up of the lactone ring. In alkaline solution this takes place spontaneously with formation of diketogulonic acid, which afterwards breaks down to threonic and oxalic acids from which the vitamin cannot be recovered by simple reduction. This does not readily happen in acid solution, and the vitamin may be oxidized to the dehydro form and quantitatively recovered by the use of the appropriate reducing agents.

Oxidation of the vitamin can occur in the absence of molecular oxygen provided the solution is activated by (1) ultra-violet light, (2) copper, (3) pyridine nucleotides, or (4) enzymes of the type of ascorbic acid oxidase. The possible significance of copper contamination has been recognized in an order by the Ministry of Food by which manufacturers of fruit concentrates containing vitamin $\mathrm{C}$ are required to satisfy the Ministry that their process plants do not come in contact with fruit juices.

It may be sufficient for industrial purposes to ensure that the boiling pans are not lined with copper, the effect of copper parts of the cold sections of the plant being disregarded. Contamination by ionic copper is likely to be much more troublesome, since the metal may be introduced in the water and carried by the fruit, which is often copper-sprayed. Substances capable of protecting the vitamin from destruction following oxidation are (l) substances which stabilize the vitamin in its oxidized (dehydro) or its reduced forms, since either are of equal value in nutrition; (2) reducing agents capable of maintaining the vitamin in the stable or reduced form; (3) buffers which keep the solvent from becoming alkaline; and (4) substances which act as anticatalysts either by depressing the ionization of copper present in the solution or by combining with ascorbic oxidases.

Reduced ascorbic acid is stable in tissue fluids and in natural and processed food materials containing appreciable quantities of copper. This stability is due to the presence of substances such as glutathione which form copper compounds of a low degree of ionization. E. Kawereau and W. R. Fearon ( $S c i$. Proc. Roy. Dublin Soc., 23, 171 ; 1944) have recently investigated a large number of substances which might protect ascorbic acid from oxidation in the presence of copper. Of all the simple solutes tested, thiourea was outstanding in its protective power. It appears to be of very low toxicity and is excreted unchanged by the kidney after administration to human subjects. It displays none of the pharmacological effects possessed by some of the substituted thioureas. The authors, however, consider that more work is required on the effects of long-continued 
administration and the possible formation of decomposition products during prolonged boiling with fruit extracts, before the general use of thiourea as a protector of vitamin C in large-scale industrial work can be advocated; but it appears most promising of all compounds tested. Boiled vegetable extracts display a similar power of protection, which in some preparations is so complete as ta suggest the presence of specific stabilizers of possibly the thiol class. Cabbage, for example, contained an unidentified volatile thiol compound and potato juice yielded an active distillate on boiling.

\section{EFFECT OF DRINKING SMALL QUANTITIES OF SEA WATER}

$\mathrm{D}$ R. W. S. S. LADELL, of the National Hospital, Queen Square, London, has studied the effects of drinking small quantities of sea water (The Lancet, Oct. 9,1943, p. 441). The work was done for the Medical Research Council's Committee on the care of shipwrecked personnel (M.R.C. War Memo. No. 8, which does not recommend the drinking of sea water). A full report of Dr. Ladell's work will be issued later.

A man requires 800-1,000 c.c. of water a day. With less than this he contracts a water debt to his tissues. With a water debt he continues to produce only 350450 c.c. of urine a day (instead of the normal 1 litre or so), whether the water debt is large or small. During this low urinary output, the urea concentration in the urine rose to as much as 6 per cent; but the total urea output was inadequate and there was nitrogen retention with a rise of blood urea. At the same time, the salt losses in the urine were high on the first day, but they fell in a day or two to a low level. The diet of each subject of all the experiments was 'shipwreck diet' of $1 \mathrm{oz}$. daily of biscuits, sweetened condensed milk, butter fat or margarine, and chocolate. This provided not more than $1 \mathrm{gm}$. of sodium chloride daily, but more than this was excreted, so that, when no sea water or saline was drunk, there was always a slight negative salt balance. There was a definite psychological value in having an extra volume of fluid to drink (water supplemented with 3.5 per cent sodium chloride solution or with sea water), even though it tasted salty.

The results, briefly stated, were that the effects of drinking up to 400 c.c. of sea water a day, when the subjects were either totally or partially deprived of fresh water, were, on the low-calorie and low-salt diet provided, an increase in the output of urine, with an improved total urea clearance; a slight gain to the body of water, because the extra water lost in the urine is less than the extra water taken in as sea water ; and an initial retention of chloride equal to the chloride lost before the subjects began to drink sea water and, after this, a full excretion of all the chloride ingested. This restoration of the total sodium chloride content of the body may have been a manifestation of the body's tendency, indicated by the work of others whose work is quoted, to conserve its extracellular, at the expense of its intracellular, fluid.

Readers interested in the medical problems presented by the survivors of shipwrecks will find useful Surgeon-Captain Critchley's book, "Shipwreck Survivors, a Medical Study" (J. and A. Churchill, London, 1943, 7s. 6d. net).

\section{FORTHCOMING EVENTS}

(Meetings marked with an asterisk * are open to the public)

\section{Saturday, March 25}

Assoctation for Scientific Photography (at the Caxton Hall Westminster, London, S.W.1), at 2.30 p.m.- "The Assessment of Lens Performance" (Mr. A. Cox: "General Theory of Lens Performance"; Mr. H. W. Martin: "Lens Types and their Characteristics"). BIOCHEMrCar SocIETY (at the Courtauld Institute of Biochemistry Middlesex Hospital, London, W.1), at 2.30 p.m.-Annual General Meeting.

Monday, March 27

Royal Societr of ARTs (at John Adam Street, Adelphi, London, W.C.2), at 1.45 p.m.-Dr. Franklin Kidd: "Dehydration of Foodstuffs" (Cantor Lectures, 2).

Tuesday, March 28

Institute of FUed (joint meeting with the British CoAl UtilizaTION RESEARCH ASSOCIATION) (at the Institution of Electrical Engineers, Savoy Place, Victoria Embankment, London, W.C.2), at 10.30 a.m.-Symposium on "Underfeed Stokers as applied to Furnaces".

INSTITUTION OF BRITISH AgRicultoral ENGINERRs (at the Royal Society of Arts, John Adam Street, Adelphi, London, W.C.2), at 1.45 p.m.-Mr. F. A. Secrett: "Mechanisation in Market Gardening" ROYAL COLLEGe of SURGEONS OF ENGLAND (at Lincoln's Inn Fields, london, W.C.2), at 4 p.m.-Prof. Arnold Sorsby: "Blindness in Childhood; Past Achievements and Present Problems".

RoYaL InstrTution (at 21 Albemarle Street, London, W.1), at 5.15 p.m.- Sir Henry Dale, G.B.E., Pres.R.S.: "Chemical Factors in Nervous Effects", 2: "The Appearances of Two of these SubINSTITUTION OF ELECTRICAL ENGINEERS (TRANSMISSION SECTION) (at Savoy Place, Victoria Embankment, London, W.C.2), at 5.30 p.m. -Discussion on the Supply and Distribution Sections, of the Report on "Electricity Supply, Distribution and Installation" prepared by Sub-Committee No. 3 of the Post-War Planning Committee (to be opened by Mr. P. E. Rycroft).

RoYal Photographic Sochetr (ScIentific and TECHNICAI GrodP) (at 16 Princes Gate, South Kensington, London, S.W.7), at 6 p.m.Annual General Meeting. Mr. F. W. Coppin: "Production of Photographic Templates". Shefritid Metaldorgicat Assocratron (at 198 West Street,
Sheffield), at 6.30 p.m.-Mr. J. H. G. Monypenny: "The Sigma Sheffield), at 6.30 p.m.-M
Phase and its Significance".

\section{Wednesday, March 29}

Institution of Nayal ARohiteors (at the Royal Society of Arts, John Adam Street, Adelphi, London, W.C.2), at 12 noon-Annual General Meeting.

ROYAL SOCIETY of ARTS (at John Adam Street, Adelphi, London W.C.2), at 1.45 p.m.-Mr. E. R. Hamilton: "Education To-day and To-morrow", 7 : "The Training of the Teacher".

\section{Thursday, March 30}

Town and Codntry Planning Association (at 1 Grosvenor Place London, S.W.1), at 1.15 p.m.-Rt. Hon. Earl De La Warr : "National Planning Policy in relation to Agriculture". RoYal INstirumon (at 21 Albemarle Street, London, W.1), at
2.30 p.m.-Mrs. Kathleen Lonsdale: "Diamonds-Natural and Artificial"'.

ROYAL COLLEGE OF SURGEONS OF ENGLAND (at Lincoln's Inn Fields, London, W.C.2), at 4 p.m.- Prof. Arnold Sorsby : "The Sulphonamides in Ophthalmology; their Use and Limitations".

INSTITUTION OF EleCTRICAI ENGINEERS (at Savoy Place, Victoria Embankment, London, W.C.2), at 5.30 p.m.-Mr. J. A. Harle and Mr. R. W. Wild : "Restriking-Voltage as a Factor in the Performance, Rating and Selection of Circuit-Breakers"; Mr. H. E. Cox and Mr. of High-Voltage Air-Blast Circuit-Breakers".

INSTITUTION OF ELECTRICAL ENGINEERS (CAMBRIDGE AND DISTRICT INSTITUTION OF ELECTRICAL ENGINEERS (CAMBRIDGE AND DISTRICT
WIRELESS GROUP) (at the University Engineering Department WIRELESS GROUP) (at the University Engineering Department,
Trumpington Street, Cambridge), at 8.15 p.m.-Mr. R. H. Angus : "Trumpington Street, Cambridge), at

\section{Friday, March 31}

OIL aNd Colour Chemists' Association (Manchester Section) (at the Engineer's Club, Albert Square, Manchester), at 2 p.m.Mr. W. A. Silvester: "Patents at Home and Abroad".

ROYAL INSTITUTION (at 21 Albemarle Street, London, W.1), at 5 p.m.-Mr. Stanley Unwin: "Publishing in War and Peace".

\section{Saturday, April I}

BRITISH Association of ChEMISTS (LONDON SECTION) (at the Chemical Society, Burlington House, Piccadilly, London, W.1), at Community",

Thursday, March 30-Tuesday, April 4

BRimish Psychologicax Socifery (at the Training Centre, Jordanhill, Glasgow, W.3).-.-Annual General Meeting. 